\title{
PENDEKATAN LINGKUNGAN DALAM REKONSTRUKSI PERTUMBUHAN PEMUKIMAN TROWULAN KUNA : SUATU PEMIKIRAN INDUKTIF
}

\author{
Oleh : Bugle M. H. Kusumohartono
}

("We are all aware that the kinds of organisms to be found in both rural and urban areas in particular part of the world depend not only on the local conditions of existence-that is, hot or cold, wet dry-but also on geography.) (Odum, $1975: 45$ ).

Para ilmuwan yang bergerak di bidang arkeologi pada umumnya sependapat, bahwa situs Trowulan adalah lokasi pusat pemerintahan kerajaan Majapahit pada kurang lebih abad ke 14 Masehi. Nāgarak rtāgama menggambarkan bahwa pertengahan abad ke - 14 merupakan masa kemasan peradaban dan kejayaan kerajaan Majapahit (Pigeaud, 1962, IV). Sedikit atau bany rak kondisi yang tercipta tersebut berkaitan dengan situasi pemerintahan yang berpusat di pemukiman kuna Trowulan.

Menurut Finch dan Terawartha, pemukiman (settlement) adalah : "....., here used as a noun, refers to the characteristic groupings of population into occupance unit together with the facilities in the form of houses and streets which serve the inhabitans." (Bintarto, 1977 :92)

Lebih lanjut Bintarto mengemukakan, bahwa rumusan mengenai pemukiman tidak dapat terlepas dari aspek-aspek daerah dan kawasan lain serta pengaruh timbal balik yang terciptakan. Situasi dan sifat hubungan di antara lokasi tempat tinggal sekelompok manusia dengan daerah yang lain di sekitarnya merupakan faktor utama pembentukan karakter dari pemukiman yang bersangkutan.

Situs Trowulan terletak kurang lebih 10 kilo meter di sebelah selatan kota Mojokerto sekarang. Jaraknya relatif jauh dari urat nadi transportasi air, yaitu sungai Brantas. Secara geografis Trowulan juga cukup jauh dari jangkauan kota-kota pusat perniagaan di sepanjang pesisir utara Jawa dan selat Madura. Hambatan jarak yang jauh dengan berbagai sarana dan prasarana perniagaan menggambarkan, bahwa pemukiman Trowulan tidak berbasiskan kehidupan perniagaan. Walaupun kegiatan perniagaan 
tidak mustahil berlangsung di antara warga pemukiman Trowulan kuna, tetapi pada hakekatnya kegiatan perniagaan tidak secara dominan menunjang kehidupan masyarakat. Dalam kaitan inilah dirasakan perlu pemahaman tentang basis kehidupan masyarakat Trowulan kuna guna menjelaskan pertumbuhan pemukiman dan peningkatan statusnya menjadi pusat pemerintahan.

Sampai dengan saat ini berbagai penelitian arkeologis di situs Trowulan pada umumnya bertujuan untuk merekonstruksi pola pemukiman. Usaha-usaha untuk merekonstruksi pola pemukiman Trowulan kuna dimulai oleh Maclaine Pont pada awal abad ini (1924 : 36 - 75, 157 - 199). Upaya yang sama diselenggarakan pula oleh Puslit Arkenas, terhitung sejak tahun 1976 sampai dengan 1984.

Disamping penelitian yang mengkhususkan kepada rekosntruksi pola, fungsi masing-masing unsur pemukiman, serta hubunga antar unsur pemukiman, terhadap situs Trowulan telah dilaksanakan serangan penelitian untuk mengungkapkan berbagai aspek kehidupan yang lain. Pusat perhatian kali ini berkisar pada masalah tekno-hidrologi, mengingat di situs Trowulan tidak sedikit dijumpai ke purbakalaan yang berupa fasilitas tekno-hidrologi. Penelitian terhadap perangkat-perangkat keairan di lingkungan situs Trowulan dilakukan oleh Maclaine Pont (1926 : 104 123), A.S. Wibowo (1977: 41 - 49), dan Karina Arifin (1983).

Berbagai permasalahan menyenai pemukiman atau kota serta sejarah pertumbuhannya merupakan obyek studi yang tidak ada habisnya bagi para ilmuwan dari berbagai disiplin. Sebagaian dari berbagai pemukiman di muka bumi ini berkembang semakin canggih karena didasari oleh faktor ekonomi. Perkembangan pada sebuah pemukiman sebagaimana digambarkan di atas diawali dari suatu pemukiman yang sederhana. Pemukiman sederhana tersebut berfungsi sebagai persinggahan. misalnya tempat para pedagang bertemu dan berinteraksi. Berbagai persingggahan semacam itu kemudian tumbuh dan berkembang seiring dengan peningkatan intensitas permintaan dan produksi di antara berbagai tempat yang berbeda.'

Pemukiman-pemukiman yang tumbuh dan berkembang karena faktorfaktor ekonomi pada umumnya didasari oleh letaknya yang strategis pada 
jalur lalu lintas perdagangan (Martindale, 1966 : 16). Sejarah kuno Indonesia menampilkan kejayaan Sriwijaya karena letaknya yang strategis tersebut :

"Whoever is lord of Malacca has his hand on the throat of Venice. As far as from Malacca, and from Malacca to China, and from China to the Moluccas, and from Moluccas to Java, and from Java to Malacca and Sumatra, (all) is in our power." (Cortesao, 1944: 287 ; Wolters, $1965: 31$ dst.).

Situasi yang sama berlangsung pula dan dialami oleh kota-kota pantai di sekitar selat Madura, karena selat Madura merupakan jalur simpang perdagangan laut (Sutjipto Tjiptoatmodjo, 1983 : 72 - 85). Tidak kurang dari Van Leur (1955) dan Schrieke (1960) mengemukakan pendapat yang senada.

Di Berbagai bagian dunia, populasi manusia cenderung meningkat. Penemuan berbagai sumber dan macam bahan mentah meningkat seiring dengan kemajuan teknologi serta peningkatan kebutuhan manusia. Perubahan dalam kehidupan material timbal balik saling mempengaruhi dengan kehidupan sosial. Setiap satuan manusia menyusun dirinya ke dalam unit-unit yang mampu memenuhi kebutuhan individu maupun kebutuhan bersamanya. Bentuk dan sifat masing-masing unit kesatuan individu tersebut tercermin secara fisik pada pemukiman-pemukiman dimana mereka tinggal.

Pada sistematika kelompok-kelompok terpenting dalam struktur sosial, Mac lver dan Page (1961 : 215) mengklasifikasikan pemukiman ke dalam kategori utama kesatuan-kesatuan wilayah tipe khusus. Pemukiman sebagai bagian dari kelompok-kelompok sosial yang luas menekankan kecanggihan mekanisme masyarakatnya pada aspek interaksi dan socialexperiences di antara warganya (Soerjono Soekanto, 1977 : 95). Dalam kaitan ini patut diperhatikan pendapat Pirenne, bahwa timbul dan tumbuh nya pemukiman tidak dapat terlepas dari kebutuhan sosial di antara individu untuk saling berjumpa (Pirenne, 1969: 56 - 60).

Dengan kata lain, selain faktor ekonomi, aspek sosial merupakan faktor utama yang mendasari timbul dan tumbuhnya sebagian pemukiman dimuka bumi ini.

Berbagai faktor utama lain berhasil diungkapkan oleh para ilmuwan dan telah memberikan pemahaman baru mengenai latar belakang perkembangan dari pemukiman. Sebuah teori yang khas telah dikemukakan oleh Von Heine-Geldern sehubungan dengan tumbuhnya kota-kota kuna di Asia Tenggara. Diajukan pendapat bahwa kota-kota kuna Asia Tenggara 
daratan maupun kepulauan tidak dapat terlepas dari landasan faktor konsep kosmologi dan yang bersifat magis-religius (Geldern, 1982).

Studi mengenai kota-kota Asia Tenggara dilakukan pula oleh Denys Lombard. (1976). Dalam penelitiannya Lombard mengkategorikan Majapahit - Trowulan ke dalam kelompok pemukiman yang berkembang antara abad ke - 9 sampai ke - 15. Kategori ini ditandai oleh pemukiman yang umumnya terletak di pusat daerah persawahan. Dalam hal ini Lombard memberikan penekanan kepada aspek pertanian padi sebagai dasar pemahaman untuk mengkaji fenomena pertumbuhan kota-kota kuna di Asia Tenggara.

Uraian-uraian di atas menggambarkan bahwa timbul dan tumbuhnya berbagai pemukiman di muka bumi ini didasari oleh berbagai macam faktor utama. Kemungkinan besar timbul dan tumbuhnya pemukiman tidak terbatas didasari oleh sebuah faktor semata. Berbagai faktor dapat sekaligus, sendiri-sendiri maupun bersama-sama mendorong pertumbuhan suatu pemukiman. Walaupun demikian terdapat satu hal yang merupakan titik persesuaian di antara berbagai faktor tersebut, yaitu basis kehidupan warga pemukiman yang bersangkutan. Basis kehidupan warga pemukiman sekali lagi memperhatikan formulasi tentang pemukiman di depan, timbal balik saling mempengaruhi dengan daerah dan kawasan di lingkungan pemukiman tersebut berlokasi.

Lokasi pemukiman Trowulan tidak terletak pada jalur lalu lintas perdagangan utama, baik sungai Brantas maupun selat Madura. Pemukiman Trowulan terletak relatif jauh di sebelah selatan sungai Brantas, pada sebuah lembah di kaki utara pegununganAnjasmoro, Welirang, dan Arjuna. Kenyataan ini mendorong lahirnya pemahaman bahwa pertumbuhan situs Trowulan tidak dapat dilepas dari faktor ketergantungan warga masyarakat terhadap mata pencaharian bercocok tanam padi.

Berkaitan dengan urian Lombardi atas, maka fokus perhatian pada tulisan ini sedikit banyak didominasi oleh faktor-faktor agraris serta keterkaitannya sebagai basis kehidupan yang melandasi pertumbuhan pemukiman Trowulan kuna. Intensitas kegiatan pertanian melibatkan pula sarana dan prasarana produksi sebagai bagian dari sistem teknologi yang menunjang kehidupan sehari-hari. Sementara itu faktor produksi berupa lahan dan air merupakan kebutuhan kolektif yang pokok dalam pertanian padi. Karena kedua macam faktor produksi tersebut bersifat terbatas dan rawan, maka penataan dengan mekanisme yang baik mutlak dijalankan.

Sebagai landasan teori yang patut dikaji guna menerangkan keterkaitan pertumbuhan pemukiman Trowulan kuna dengan basis kehidupan 
pertanian, ialah pendapat yang diajukan oleh Gideon Sjuberg (1965:25 31). Sjoberg berpendapat bahwa timbul dan tumbuhnya sebuah pemukiman atau kota berhubungan erat dengan faktor-faktor: 1. Basis ekologi yang memadai, 2. Teknologi yang maju, dan 3. Struktur kekuasaan yang kuat atas ofganisasi sosial yang kompleks. Teori ini terpilih sebagai titik tolak pemikiran mengingat terdapatnya persesuaian yang tegas dengan pemikiran lanjut salah satu rujukan utama tulisan ini, yaitu teori yang diajukan oleh Lombard.

\section{III}

Dua ubahan (variable) utama yang dilibatkan dalam telaah ini ialah pemukiman dan kegiatan pertanian padi. Lingkup dari ubahan pemukiman ialah pemukiman Trowulan kuna pada kisaran waktu detik penempatannya sebagai pusat pemerintahan kerajaan Majapahit. Dalam hal ini meliputi masa-masa sebelum dan sesudah detik peningkatannya dari status semula, yaitu pemukiman biasa ke status yang lebih tinggi, yaitu pusat pemerintahan kerajaan. Di lain pihak, lingkup dari ubahan kegiatan bercocok tanam padi meliputi aspek-aspek ekologi, teknologi, dan sosialpolitik.

Dengan berlandaskan pada ilmu lingkungan, kedua ubahan utama yaitu pemukiman dan kegiatan pertanian padi dipandang sebagai suatu kesatuan majemuk yang berkaitan. Ilmu lingkungan mengintergrasikan berbagai ilmu yang mempelajari hubungan antar jasad hidup, termasuk manusia, dengan lingkungannya (Soeriaatmadja, 1979 :1). Selanjutnya diungkapkan :

".... Tidak perduli ilmu apapun namanya, asal menyangkut hubungan antara jasad hidup dengan lingkungannya, fokusnya selalu tertuju kepada proses kecermatan pemindahan energi dalam berbagai sistem. Nampak, apapun materi yang tersebar dalam ruang di atas muka bumi ini, tidak perduli tumbuhan, hewan, mobil, gedung, kota atau wilayah dan lain-lain, mempunyai implikasi melakukan pemindahan energi. Jadi, jasad hidup dapat dianggap sebagai materi, tempat siklus energi itu beroperasi. Waktu juga penting, sebab sebuah proses tidak akan sampai kepada ambang suatu tingkat, apabila tidak diberi cukup waktu untuk mencapainya. Rangkaian keanekaragaman yang tak terputus-putus daripáda sifat morfologi dan genetika menentukan tinggi rendah dinamika organisme hidup, populasi, dan komu nitas |di muka bumi. Karena hal itu khas dalam jasad hidup, maka penting | pula untuk diperhatikan."

Ilmu lingkungan sebagai wadah bagi pendekatan antar disiplin pada 
dasarnya menerapkan berbagai asas dan konsep ekologi. Ekologi adalah cabang dari disiplin biologi

'.....the study of the earth's 'households' including the plants, animals, microorganism, and people that live together as interdependent components..... ecologi can be viewed as 'the study of the structure and function of nature' - it is understood that mankid is a part of nature." (Odum, $1975: 45)$.

Dalam kerangka pemikiran kajian ini maka manusia merupakan subyek yang bersama-sama dengan kebudayaannya menempatkan diri sebagai salah satu unsúr alam.

Pendekatan ekologis berusaha mendapatkan spesifikasi vang lebih tepat mengenai hubungan antara manusia dengan transaksi biologis, serta proses alam tertentu, dan memasukkan semua itu ke dalam satu kerangka analisis yaitu ekosistem. Ekologi adalah "the sum total of phy. sical features and organisms occuring in a given area and their interactiun" (Damon, 1977 : 266). Dengan demikian konsep ekositem menekankın kesalingtergantungan antara komunitas organisms dengan situasi alam di mana komunitas itu berada.

Berdasarkan uraian di atas, maka pemanfaatan konsep ekosistem dalam telaah ini adalah mengkaji dinamika ubahan kegiatan bercocok tanam padi serta bagaimana cara sistem tersebut berkembang dan menriptakan imbas bagi ubahan pemukiman. Dinamika yang terjadi ialah saling tukar energi menurut pola tertentu di antara berbagai unsur ekosiste $\mathrm{L}_{\mathrm{i}}$, yang disebut sebagai fisiologi ekstern. Di lain pihak berlangsung pula dinamika proses pemeliharaan keseimbangan dari sistem yang bersangkutan atau homeostatis (the balance of nature), yang disebut dengan fisiologi intern (Geertz, 1976 : 4).

\section{IV.}

Sesuai dengan judulnya, telaah ini tidak lebih dari suatu proses pemikiran induktif belaka. Sebuah penelitian yang ideal selalu berusaha menerapkan dinamika pemikiran induktif dan deduktif sekaligus. (Sutrino Hadi, I, 1978). Sebagaimana runtutan uraian di atas, hipotesis yang lingkup rumusannya meliputi aspek ekologi, teknologi dan sosial politik, serta potensinya sebagai penunjang pertumbuhan pemukiman Trowulan kuna, merupakan hasil akhir dari proses pemikiran induktif tersebut. Upaya untuk mengendalikan warna pemikiran pada alur keilmuan yang obyektif dilaksanakan dengan menyandarkan diri pada pengkaitan dan 
pengevaluasian masalah pada landasan teori yang relevan. Sebagai mana perlakuan pada suatu proses pemikiran induktif, telaah ini tidak diarahkan kepada suatu pengujian hipotesis melalui ubahan operasional dan field study. Walaupun demikian, gambaran yang sedikit lebih luas mengenai fakta lapangan dari ubahan-ubahan diatas akan disajikan di bawah.

Pulau Jawa merupakan salah satu daerah subur di Nusantara. Benteng alam berupa paduan gunung-gunung berapi dengan lembah-lembah sungai, ditunjang oleh keadaan iklim yang memadai, mendorong tumbuhnya kehidupan berpola agraris. Kemampuan besar dari daya dukung kehidupan berpola agraris tersebut dapat dinilai lewat tumbuhnya strukturstruktur sosial berbentuk kekuasaan politik kerajaan-kerajaan besar di pulau Jawa pedalaman, maupun selebaran berbagai kepurbakalaan berkualitas tinggi di wilayah yang kaya dengan hasil pertanian. Dalam kaitan ini dapat dibayangkan bahwa pola kehidupan agraris pada masa itu mampu membawa pada tingkat kesejahteraan dan kemakmuran yang mantap.

Relung ekologi yang khas pada lembah-lembah sungai di pulau Jawa telah melahirkan bentang persawahan yang selalu terairi dan subur. Berbagai data arkeologi berhasil menggambarkan kegiatan/eksploatasi dan konservasi sumber daya alam, terutama pada aktifitas persawahan itu sendiri. Selain kegiatan yang berhubungan langsung dengan pengelolaan sumber daya alam, patut pula diperhatikan aspek-aspek ekonomis-sosiologis mengingat subyek / utama dalam aktifitas pertanian padi adalah petani. Dalam kaitan ini James C. Scott (1981 : 19) secara tegas menyatakan :

"Perilaku ekonomis yang khas dari keluarga petani yang berorientasi subsistensi merupakan akibat dari kenyataan bahwa, berbeda dari satu perusahaan kapitalis, ia sekaligus merupakan satu unit konsumsi dan unit produksi. Agar bisa bertahan sebagai satu unit, maka keluarga itu pertama-tama harus memenuhi kebutuhannya sebagai konsumen subsistensi yang boleh dikatakan tak dapat dikurangi lagi dan tergantung kepada besar kecilnya itu. Memenuhi kebutuhan-kebutuhan manusiawi yang minimum itu dengan cara yang dapat diandalkan dan mantap merupakan kriterium sentral yang menjalin soalsoal seperti memilih bibit, teknik bercocok tanam, penentuan waktu, rotasi tanam, dan sebagainya."

Pernyataan diatas secara ekologis memperlihatkan suatu interaksi bahkan suatu ketergantungan yang jelas dari para petani terhadap potensi lahannya. Dilain pihak para petani terkungkung didalam relung ekologi rawan yang nota bene adalah hasil karya mereka sendiri. Sistem sawah dalam kerangka ekologis merupakan suatu sistem ekologi yang diperkhusus (specialized ecosystem). Sedikit saja ketidak seimbangan berlangsung pada relung ekologi yang bersangkutan, penurunan kualitas hidup pada 
skala sedang akan terjadi. Dalam kenyataannya kungkungan relung ekologi rawan yang memagari kegiatan pertanian padi berhasil diatasi melalui berbagai proses kemajuan teknologi maupun penataan dalam kehidupan sosialnya.

Konsentrasi telaah ekologi pertanian padi ini bergerak di seputar dinamika dari ekosistem artifisial yang diciptakan. Pertambahan populasi penduduk dan peningkatan jumlah keluarga telah mendorong ke arah perluasan lahan pertanian atau ekstensifikasi (Bugie Kusumohartono, 1984 : 47). Hal ini pun dikung kenyataannya berlangsungnya usaha-usaha ekstensifikasi bagi peningkatan jumlah produksi, dilaksanakan pula usaha usaha intensifikasi. Upaya intensifikasi berlangsung dalam berbagai bentuk, termasuk diantaranya adalah penciptaan sistem irigasi pada lahan pertanian kering (OJO. XII : 124). Aktifitas ekstensifikasi dan intensifikasi pada hakekatnya adalah proses memasukkan atau menambahkan energi menurut pola tertentu yang dikenal sebagai fisiologi ekstern.

Aktifitas intensifikasi dan ekstensifikasi dalam sistem pertanian pada sedikit banyak menciptakan perubahan pada relung ekologi. Penambahan energi pada satu komponen ekosistem berarti memindahkan energi tersebut dari komponen yang lain. Pada dasarnya setiap perubahan di dalam ekosistem akan riskan akibatnya pada relung ekologi yang rawan sifatnya tersebut. Sebagai upaya memelihara keseimbangan dari sistem yang bersangkutan, para petani berhasil memberi suplai energi pada komponenkomponen ekosistem "yang membutuhkan atau kekurangan". Suplai energi tersebut dapat dijabarkan dalam bentuk introduksi teknologi canggih maupun sistem penataan kehidupan sosial warga petani. Proses suplai energi tersebut mampu menciptakan kondisi yang homeostatis, atau yang dalam ekologi disebut dengan istilah fisiologi intern.

Pada akhirnya telaah di atas telah mengungkapkan serba sedikit tentang kemampuan manusia masa lampau, terutama pada periode pengaruh kebudayaan Hindu di Indonesia dalam mengelola sumber daya alam. Di garis bawahi bahwa pola hubungan antara petani dengan lingkungan alamnya terjalin secara khas dalam tatanan nilai yang imanen atau holistis (Otto Soemarwoto, 1978 : 15 - 18). Pola dan sistem yang demikian canggih tersebut pada saat sekarang masih dapat disaksikan rekamannya pada berbagai data arkeologis. Campur tangan perekonomian kolonial pada masa yang kemudian telah "memporakporandakan" pola dan sistem tersebut (Geertz, 1976 : 51 - 113), yaitu pola dan sistem yang mampu menunjang tumbuh dan hadirnya suatu pemukiman kuna di Trowulan. 


\section{DAFT A R PUS TAKA}

Bintarto, R., 1977. Geografi Sosial, Jogjakarta : UP Spring.

Brandes, J.L.A., 1913. "Oud-Javaansche Oorkonden", Verhandelingen van het Bataviaansche Genootschap van kunsten en Wetenschappen. Deel LX, Batavia: Alhrecht \& Co.

Bugie M.H. Kusumohartono (et. al.), 1984. Pola Tata Guna Lahan Masyarakat Indonesia Kuna (Suatu Sumhangan Pemikiran Bagi Pemhinaan Lingkungan di Indonesia), Proyek PPPT - Pemhinaan Kreattvitas Mahasiswa.

Cortesa o, Armando (trans. and ed.), 1944. The Suma Oriental of Tome Pires. II, London : Hakluyt Society.

Damon, Alhert, 1977. Human Biology and Ecology, New York : W.W. Norton and Company.

Geertz, Clifford, 1976. Involusi Pertanian: Proses Peruhahan Ekologi di Indonesia, Jakarta : Bhratara K.A.

Heine - Geldern, Rohert von, 1982. Konsepsi tentang Negara dan Kedudukan Raja di Asia Tenggara, Jakarta: C.V. Ra jawali

Karina Arifin, 1983. Waduk dan Kanal di Pusat Kerajaan Majapahit Trowulan Jawa Timur, Skripsi FSUI.

Leur, J.C. van, 1955. Indonesian Trade and Society: Essays in Asian Social and Economic History, ' s-Gra venhage.

Lomhard, Denys, "Sumhangan kepada Sejarah Kota-kota di Asia Tenggara", Masyarakat Indonesia, III No. 1 LIPI, hlm. 51 - 69.

MacIver, R.M. and Charles H. Page, 1961. Society, an Introductory analysis. London: MacMillan \& Co. Ltd.

Martindale, Don, 1966. "Prefatory Remarks: The Theory of the City", dalam Max Weher, the City, New York/London. 
Odum, Eugene P., 1975. Ecology, New York: Holt, Reinhard and Winston.

Otto Soemarwoto, 1978. "Ekologi Desa, Lingkungan Hidup dan Pembangunan", Prisma. Tahun VII Nomor 8, September, lakarta : LP3ES hlm. 12 - 31.

Pigeaud, Theodore G. Th., 1962. lava In the Fourteenth Century: A Study In Cultural History. IV The Hague- Martinus Nijhoff.

Pirenne, Henri, 1969. Medieval Cities and the Revival of Trade, New lersey/ Princeton .

Pont , Maclaine. 1926. H., OV., Bijlage G., hlm. 104 - 123.

Schrieke, B., 1960. Indonesia Sociological Studies. I, the Hague Bandung: W. van Hoeve.

Scott, lames, 1981. Moral Ekonomi Petani, Pergolakan dan Subsistensi di Asia Tenggara, lakarta: LP3ES.

Soeriaatmad ja, R.E., 1979. llmu Lingkungan, Bandung: Penerbit ITB.

Soer jono Soekanto, 1977. Sosiologi Suatu Pengantar, Yayasan Penerbit UI.

Sukarto Karto Atmojo, M. M., 1979. Struktur Masyarakat lawa Kuna pada laman Mataram Hindu dan Ma japahit, Yogyakarta: PPSK UGM.

Sut jipto T jiptoatmod jo, 1983. Kota-kota Pantai di Sekitar Selat Madura (abad XVII sampai medio abad XIX), Diss. FS UGM.

Sutrisno Hadi, 1978. Metodologi Research, I., Yogyakarta: Yayasan Penerbit F. Psi UGM.

Sjoberg, Gideon, 1965. The Preindustrial City: Past and Present, New York/London. 
Wihowo, A. S., 1977. "Fungsi Kolam Buatan di Ihu Kota Malapahit", Ma|alah Arkeologi, Th. II No. 3, Lemhaga Arkeologi FSUI, hlm. 41.49.

Wolters, 0.W., 1965. Early Indonesian Commerce: A Study of the Origins of Srivi|aya. Ithaca, New York: Cornell University Press. 